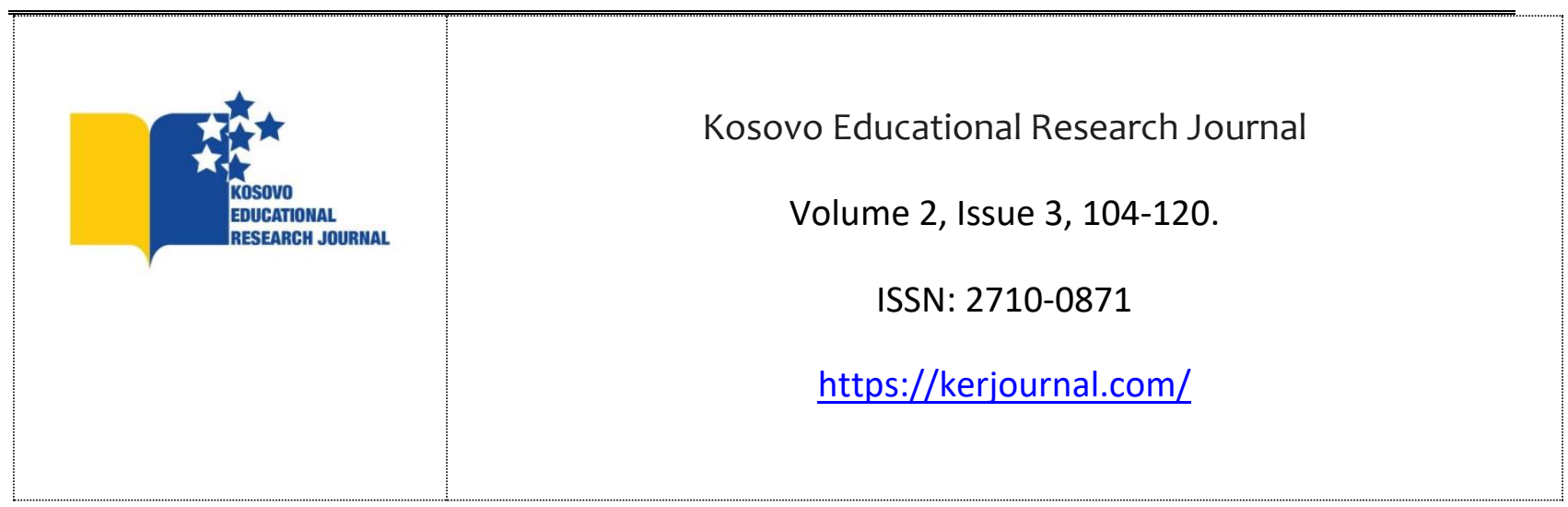

\title{
Uluslararası Öğrencilerin Yükseköğretim Harcamalarının Değerlendirilmesi
}

\section{Sümeray CENOLARi*}

\author{
Çanakkale Onsekiz Mart Üniversitesi
}

\begin{abstract}
Özet: Bu araştırmada, Türkiye'de öğrenim gören uluslararası öğrencilerin genel olarak yükseköğretim harcamalarının değerlendirımesi yapılmıştır. 2018-2019 yılları arasında Çanakkale'de yükseköğrenim görmek amacıyla gelen on beş kadın ve beş erkek toplam yirmi kişiden oluşan öğrenciyle yarı yapılandırlmış görüşme formu kullanılarak görüşmeler yapıımıştır. Araştırma sonuçlarına göre, uluslararası birinici öğretim öğrencilerine kıyasen, ikinci öğretim öğrencilerinin dönem başı harç miktarların ortalama üç kat daha fazla olduğu tespit edilmiştir. Ayrıca TÖMER öğrencilerinin de lisans öğrencilerine kıyasen daha fazla harç ödediği ve dönem başı kitap harcamalarının da daha fazla olduğu tespit edilmiştir. Buna mukabil tıp öğrencilerin de diğer bölümlerde okuyan öğrencilere kıyasen daha çok harç ücreti ödedikleri ve dönem başı daha fazla kitap harcamaları yaptıkları belirlenmiştir. Araştırmada, yirmi uluslarası öğrenciden beşi yani dörtte birnin burs aldığı,yani çoğunun burs almadığı ve ek işe ihtiyaç duydukları tespit edilmiştir.
\end{abstract}

Anahtar Kelimeler: "Türkiye", "yükseköğrenim", "uluslarası öğrenciler", "uluslararası öğrenci harcamaları", "eğitim harcamaları".

To cite this article: Cenolari, S. (2021). Uluslararası Öğrencilerin Yükseköğretim Harcamalarının

Değerlendirilmesi. Kosovo Educational Research Journal, 2(3). 104-120. 


\title{
Assessment Of Higher Education Expenditures Of International Students
}

\begin{abstract}
In this study, the higher education expenditures of international students studying in Turkey were evaluated in general. Between 2018-2019, fifteen women and five men who came to see higher education in Canakkale were interviewed using a semi-conducted interview form with a total of twenty students. According to the results of the research, it was found that compared to international students, Second students were on average three times more likely to receive tuition per semester. In addition, it was found that TÖMER students also pay more tuition than undergraduates, and book expenses per semester are also higher. On the other hand, it was determined that medical students also pay more tuition fees compared to students studying in other departments and spend more books per semester. In the study, it was found that five out of twenty international students, i.e. a quarter, received scholarships, that is, most of them did not receive scholarships and needed additional work.
\end{abstract}

Keywords: "Turkey", "higher education", "international students", "international student spending", "education spending".

\section{Giriş}

Yükseköğretimdeki rekabet, gittikçe küresel bir boyut kazanmaktadır. Gelişmekte olan ülkelerde, genç nüfus oranı yüksek olduğundan gelişmiş ülkelere doğru yükseköğretim talebi artmaya başlamıştır. Bu talepler doğrultusunda hükümetler, bütçelerini artırmamış, sadece yükseköğretim kurumları daha fazla esneklik kazanmıştır. Ülkelerin yükseköğretim sistemleri öğrenci hareketliliğine daha çok önem vermeye başlamışlardır(Yükseköğretim Kurulu, 2007). 2000'li yıllara yaklaşınca, yükseköğretimin kitleselleşmesi, küreselleşmesi ve üniversitelerin bilgi endüstrilerine dönüşmesi sağlanmıştır(Gibbons, 1998). Öğrenci hareketliliği, gelişmiş ülkeler açısından ekonomik girdi olarak nitelendirilirken, gelişmekte olan ülkeler açısından ise kıt olan kaynakların gelişmiş ülkelere aktarılması olarak tanımlanmıştır. Örneğin, Afrika ve Asya ülkesindeki öğrenciler burslu ya da özel olarak yükseköğretim için gelişmiş ülkelere yönelmişlerdir.

Türkiye Cumhuriyeti'nde yükseköğretim devlet kurumları ve özel kurumlar üzerinden yapılmaktadır. Yükseköğretim kurumları yasaların izniyle kurulmuş, yasalarla koruma altına alınmışlardır.4 Kasım 1981 tarihli, 2547 sayılı Yükseköğretim Kanunu’na göre yükseköğretim: Milli eğitim sistemi çerçevesinde, ortaöğretime dayalı, en az dört yarı yılı kapsayan her kademedeki eğitim - öğretimin tümüdür. Yükseköğretim kurumu olarak üniversiteler, yüksekokullar, konservatuvarlar, araştırma ve uygulama merkezleri, meslek yüksekokulları, 
vakıflar yer almaktadır. GSYH içinde yükseköğretime ayrılan bütçe 2015-2019 yılları arasında \%0,92'den \%0,74'e gerilemiştir.2019 y1lında hem merkezi yönetim bütçesi hem de GSYH içinde yükseköğretime ayrılan payda ciddi bir azalma yaşanması, Türkiye'nin yükseköğretim sisteminin büyüme eğilimiyle uyumlu olmamasıdır(Yalçın, A. 2019). 2922 Sayılı Kanun’un 3. maddesi uyarınca ve Yükseköğretim Kurulu onayı ile uluslararsı öğrencilerin Türkiye'de öğrenim görme hakkı vardır. Türkiye hem öğrenci çeken hem de öğrenci gönderen bir ülke konumundadır. Eğitimin uluslararasılaşması teknoloji transferlerini ve kültürler arası iletişimi de artırmaktadır (Demirel, Ö., ve Önsoy, R. 1996).

OECD (2018: 201) tanımına göre uluslararası öğrenci, öğrenim görmek amacıyla başka bir ülkeye giden kişi anlamına gelmeketdir. UNESCO (2009: 250) ise, "öğrenmek görmek amacıyla, ülke veyahutta bölge sınırları dışında bulunan ve bulunduğu ülkenin uyruğuna ait olmayan öğrencidir"' şekilinde tanımla yapılmıştır. Bu tanımlaradan yola çıkarak uluslararası öğrenci, uyruğuna ait olmayan bir ülkede eğitim görmek amaciyla bulunan kişi olarak tanımlanabilir(Mammadov, R, Baykara, B, Karimov, B, 2020).Uluslararası öğrencilere tüm üniversitelerde öğrenim görme olanağı verilmiş ve uluslararası öğrencileri kabul etmek isteyen üniversitelerde ön lisans ve lisansta- birinci öğretim, ikinci öğretim,- uzaktan eğitim ve açık öğretim programlarında uluslararası öğrenciler için kontenjanlar ayrılmıştır. Üniversitelerce belirlenecek esaslara göre ve yurt dışından gelecek öğrencilerin maddi olanaklarının Türkiye'de yükseköğrenimlerini sürdürmeye olanak tanıması amacıyla maddi bir güvence miktarı eklenmiştir. Uluslararası öğrenciler için üniversiteleri tanıtıcı doküman ve kataloglar hazırlanmış, üniversitelerin yurtdışında eğitim fuarlarına katılmaları teşvik edilmiş ve uluslararası öğrenci ofisleri açılmıştır. Bu durumlar uluslararası öğrencilerin Türkiye'ye gelişini kolaylaştırması ve artırmasını sağlamak amacıyla yapılmıştır(Eğitim Ekonomisi İş Konseyi Raporu Mart, 2013).Türkiye'ye gelen uluslararası öğrencilere ilişkin rakamlar incelendiğinde, ülkedeki eğitim kurumlarına en fazla ilgiyi Orta Asya-Türki Cumhuriyetinden gelenlerin olduğu söylenebilinir. (Radmard, S. 2017).

Tablo 1. Yıllara Göre Türkiye'de Eğitim Alan Uluslarası Öğrenci Sayıları

Eğitim-Öğretim Y1lı

2013-2014

2014-2015
Öğrenci Sayısı

48183

72178 
$\begin{array}{rr}2015-2016 & 87903 \\ 2016-2017 & 108076 \\ 2017-2018 & 125138 \\ 2018-2019 & 154505\end{array}$

Tablo 1'e bakıldığında, 2013 yılına göre öğrenci sayılarında belirgin bir artışın olduğu görülemektedir. Yükseköğretim Bilgi Sistemi’nden alınan verilere göre, 2018-2019 yılında Türkiye'ye en fazla yükseköğretim için öncelikle Suriye, Azerbaycan, Türkmenistan, Irak, İran Afganistan, vb. ülkelerden gelen öğrencilerin olduğu tespit edilmiştir. Türkiye'de eğitim alan öğrencilerin çoğunluğu komşu ülkelerdendir. Oran bakımından söyleyecek olursak Türki cumhuriyetlerinden gelenler birinci sırada, ikinci sırada Arap ülkelerinden gelen öğrenciler oluşturmaktadır. Öyle ki Türkiye'nin Türk ve İslam dünyasıdan öğrencileri çektiğini söyleyebiliriz. Uluslarası öğrencilerin Türkiye’yi tercih etme nedenleri ise tarihi bağlar, kültürel, etnik, dinsel açıdan yakınlık, akraba varlığı olarak sıralanabilir(Akbaslı, 2018). Bunun dışında, hayat tecrübesini artırmak, ülkenin saygınlığı, ülkedeki refah ve güvenlik, eğitim masrafları, öğrenci vizesi kolaylığı ve mezun olunca iş bulma kolaylığı gibi nedenler sıralanabilir.

Uluslararası öğrenciler, özellikle İktisadi ve İdari Bilimler, Mühendislik, Sağlık, Eğitim alanlarındaki branşlara yoğunlaştığını söyleyebiliriz. Bunlara ek olarak devlet üniversitelerinde Fen-Edebiyat ve İlahiyat bölümleri de çok tercih edilen alanlar olmuştur.En çok tercih edilen ilk beş devlet üniversitesi: Anadolu Üniversitesi, İstanbul Üniversitesi, Orta Doğu Teknik Üniversitesi, Ankara Üniversitesi ve Marmara Üniversitesi’dir(DEIK, 2013).

\section{Amaç}

Türkiye'de yüksek öğrenim gören uluslarası öğrencilerin eğitimlerini karşılamak amacıyla, okul harçları, kitap harcamaları, yurt ücretleri, beslenme,giyim ve yol gibi harcamaları ile kişisel ihtiyaçlarını gidermek amacıyla yaptıkları toplam aylık harcamaların neler/ ne kadar olduğunun tespit edilmesi amaçlanmıştır.

\section{Yöntem}

Uluslarası öğrencilerin görüşlerini nitel yollarla belirlemeyi amaçlayan bu araştırmada, durum çalışması yöntemi kullanılmıştır. Durum çalışması yönteminde veriler, gözlem, görüşme, dokümanlar yoluyla elde edilir(Merriam, 2009). Olgular, olaylar, algılar doğal ortamda gerçekçi ve bütüncül bir biçimde ortaya koyulur(Yıldırım ve Şimşek, 2011).Araştırmada, 2018-2019 
yılında, Çanakkale'de yüksek öğrenim görmek için yurtdışından gelen on beş kız öğrenci ile beş erkek öğrenciye yarı yapılandırılmış görüşme formu aracılığıyla sorular sorularak görüşmeler yapılmıştır. Araştırmada, ulaşılabilir uluslarası öğrencilerle görüşme yapıldığından, bilgi toplamak amacıyla kolay ulaşılabilir örneklem seçilmiştir. Öğrencilerin sorulara verdikleri samimi yanıtlar araştırmanın geçerlik ve güvenirliğini sağlamaktadır. Araştımamızın modeli tarama modelidir, uluslarası öğrencilerle yapılan grüşmelerde alınan veriler, olduğu gibi betimlenmiştir. $\mathrm{Bu}$ öğrencilerle okudukları üniversitede $18 \mathrm{dk}, 18 \mathrm{dk}, 18 \mathrm{dk}, 20 \mathrm{dk}, 20 \mathrm{dk}$ dakika olmak üzere toplamda $94 \mathrm{dk}, 1$ saat $5 \mathrm{dk}$ süreyle görüşmeler yapılmıştır.

\section{Çalışma Grubu}

2018-2019 yılında, Çanakkale'de yüksek öğrenim görmek için yurtdışından gelen on beş kız öğrenci ile beş erkek öğrenciyle görüşme yapmadan önce kendilerinden izin alınmış, gönüllü olan öğrencilerle görüşmeler gerçekleştirilmiştir. Araştırmamızda yer alan uluslararası kız öğrenciler, KÖ1....KÖ15 şeklinde, erkek öğrenciler ise EÖ1......EÖ5 şeklinde kodlanmıştır. Uluslararası öğrencilerin biri yüksek lisans öğrencisi olmak üzere diğerleri lisans öğrencileridir.

Sınırlııklar: Araştırma, 2018-2019 yılında, Çanakkale'de yüksek öğrenim görmek için yurtdışından gelen on beş kadın öğrenci ile beş erkek öğrenciyle yurtta yapılan görüşmelerle sinırlidir.

\section{Verilerin Toplanması Ve Analizi}

Yarı yapılandırılmış görüşme formu, literatür taraması yapılarak, bilgili kişilerin gözetimi altında oluşturulmuştur. Uluslararası öğrencilerle yapılan görüşmeler sonucunda alınan yanıtlar doğrultusunda, çıkan olası sonuçlar değerlendirilmiştir. Ses kaydı alınarak toplanan veriler deşifre edilmiştir.Deşifre edilen verilerden mevcut durum-harcamalarla ilgili rakamlar ortaya koyulmuş, altıncı görüşme sorusunda, ise öğrencilerin yaptıkları diğer harcamalar ile ilgili kategori ve kodlar oluşturulmuştur. Yarı yapılandırılmış görüşme formu iki kısımdan oluşmaktadır. Birinci kısmında, öğrencilerin kişisel bilgileri; cinsiyet, medeni durumu, yaşı, geldikleri ülkeler, öğrenim durumu ve okudukları bölüme yönelik sorulardan oluşmaktadır.İkinci kısımda ise, Bir dönemlik okul harcı miktarı ile dönem başı kitap harcamaları; burs durumu; Yurtta ücretli /ücretsiz kalma durumu; toplam aylık harcamalar(kiralık daire veya- yurta kalan öğrenciler için, beslenme, giyim, yol); ek işe ihtiyaç duyma durumu ve yapılan diğer harcamalara yönelik altı sorudan oluşmaktadır. 


\section{Bulgular ve Yorumlar}

Uluslarası on beş kız öğrenciye uygulanan yarı yapılandırılmış görüşme formuna göre, ikinci öğretim öğrencilerinin birinci öğretim öğrencilerine kıyasen okul harç miktarlarının daha yüksek olduğu tespit edilmiştir. İkinci öğretim öğrencilerinden sonra tıp öğrencilerinin okul harç miktarlarının yüksek olduğu söylenebilinir. Dönem başı kitap harcamalarında, önce tıp öğrencilerinin sonra ise ilahiyat ve PDR (Psikolojik Danışmanlık Ve Rehberlik) öğrecilerinin harcamalarının diğer bölümlerdeki öğrencilere göre daha yüksek olduğu saptanmıştır. Uluslararası beş erkek öğrenciye uygulanan yarı yapılandırılmış görüşme formuna göre TÖMER-Türkçe Hazırlık okuyan öğrencilerin okul harç miktarının yüksek olduğunu; iktisat bölümünde okuyan erkek öğrencinin ise dönem başı kitap harcamalarının diğer öğrencilere göre daha yüksek olduğu tespit edilmiştir. Yurt ücretlerine baktığımızda erkek öğrencilerin 720 tl ile 115 tl maksimum ile minimum arasında yurda ödeme yaptığı; kız öğrencilerin ise 150 tl ile 450 tl arasında olduğu; toplam yirmi uluslarası öğrenciden 13'ün yurt ücreti ödediği tespit edilmiştir. Az burs ücreti ödeyen öğrecniler burslandı1rlmış öğrencilerdir. Uluslarası öğrencilerden bir öğrenci hariç diğer hepsi yurtta kalmakta; bu öğrencilerden en yüksek toplam aylık harcama Rusya ülkesinden gelen erkek öğrenci-2000tl; iken en düşün aylık harcama ise Suriye'den gelen kız öğrenci-400 tl 'dir. Uluslarası öğrencilerin 11'i ek işe ihtiyacının olduğunu geri kalan 9'u ise ek işe ihtiyacının olmadığını belirtmişlerdir. Uluslararası öğrencilerin, diğer harcamalar kategorisinde, kişisel harcamalar kodunda, ulaşım ücretleri, eğlence, gezi, araç-gereç temini, dişarda yemek yeme, arıza sorunları yer almaktadır. Bu harcamalardan en fazlasını uçak biletleri oluşturmakta; ardından ise tıp öğrencilerinin bölümleriyle ilgili kullanacakları araç-gereçler oluşturmaktadır.

Tablo 2. Uluslarası Kız Öğrencilerin Yaşları, Geldikleri Ülkeler, Bölümleri Ve Görüşme Süreleri

$\begin{array}{ccccc}\text { Katılımcılar } & \text { Yaşlar } & \text { Ülkeler } & \text { Bölümler } & \text { Görüşme Yeri Ve } \\ \text { KÖ1 } & 21 & \text { Sirbistan } & \text { Tıp } & \text { Dakikası } \\ \text { KÖ2 } & 21 & \text { Sırbistan } & \text { Tıur 25dk. } \\ \text { KÖ3 } & 21 & \text { Sirbistan } & \text { Türk Dili Ve Edebiyat1 } & \text { Yurt 20dk. } \\ \text { KÖ4 } & 19 & \text { Arnavutluk } & \text { Turizim } & \text { Yurt 18dk. }\end{array}$




\begin{tabular}{|c|c|c|c|c|}
\hline KÖ5 & 19 & Arnavutluk & İktisat & Yurt \\
\hline KÖ6 & 19 & Arnavutluk & Acil Yardım Ve Afet Yönetimi & Yurt \\
\hline KÖ7 & 20 & Arnavutluk & Aci Yardım Ve Afet Yönetimi & Yurt \\
\hline KÖ8 & 20 & Suriye & Tip & Yurt \\
\hline KÖ9 & 21 & Suriye & Sınıf Öğretmenliği & Yurt \\
\hline KÖ10 & 20 & Kosova & Hemşirelik & Yurt \\
\hline KÖ11 & 20 & Kosova & İlk Ve Acil Yardım & Yurt \\
\hline KÖ12 & 19 & Avusturya & İlahiyat & Yurt \\
\hline KÖ13 & 19 & Misir & İlahiyat & Yurt \\
\hline KÖ14 & 20 & Irak & İlahiyat & Yurt \\
\hline KÖ15 & 21 & Türkmenistan & PDR & Yurt \\
\hline
\end{tabular}

Tablo 2 verilerine göre, toplam on beş kız öğrenciden üç tanesi Sırbistan, dört tanesi Arnavutluk, iki tanesi Kosova, iki tanesi Suriye, bir tanesi Türkmenistan, bir tanesi Misır, bir tanesi Irak, bir tanesi de Avusturya ülkelerinden gelmişlerdir. Sırbistan ülkesinden gelen üç kız öğrenciden ikisi tıp, biri Türk Dili ve Edebiyatı, bölümlerinde lisans öğrenimi görmektedirler. Arnavut ülkesinden gelen iki tane kız öğrenci Acil Yardım Ve Afet Yönetimi lisans bölümünü okurken, bir tane öğrenci iktisat bölümünde, diğeriise Turizim Fakültesi'nde öğrenimine devam etmektedir. Kosova ülkesinden gelen iki kadın öğrenciden biri Hemşirelik, diğeri de İlk ve Acil Yardım bölümünü okurken, Avusturya'da yaşayıp Türkiye'ye okumak için gelen ve şu anda Arapça hazırlık okuyan bir türk öğrenci ile Irak ülkelerinden gelen iki kız öğrenciden ikisi de İlahiyat, Mısır ülkesinden bir kız öğrenci ilahiyat, Türkmenistan ülkesinden gelen bir kız öğrenci PDR, Suriye'den gelen iki kız öğrencinden biri Tıp, diğeri de Sınıf Öğretmenliği bölümünde öğrenim görmektedirler. Ulusrarası kız öğrencilerin yaşlarına baktığımızda beş tanesi 19, beş tanesi 20 ve beş tanesi de 21 yaşındadır. Bu öğrencilerle kaldıkları yurtta $25 \mathrm{dk}, 20 \mathrm{dk}, 18 \mathrm{dk}, 20 \mathrm{dk}, 20 \mathrm{dk}, 19 \mathrm{dk}, 22 \mathrm{dk}, 23 \mathrm{dk}$, $25 \mathrm{dk}, 20 \mathrm{dk}, 25 \mathrm{dk}, 19 \mathrm{dk}, 19 \mathrm{dk}, 20 \mathrm{dk}, 23 \mathrm{dk}$ olmak üzere toplamda 318 dakika, 5 saat $3 \mathrm{dk}$. görüşme yapılmıştır.

Tablo 3. Uluslarası Erkek Öğrencilerin Yaşları, Geldikleri Ülkeler, Bölümleri Ve Görüşme Süreleri 


\begin{tabular}{|c|c|c|c|c|}
\hline Katılımcılar & Yaşlar & Ülkeler & Bölümler & $\begin{array}{l}\text { Görüşme Yeri Ve } \\
\text { Dakikası }\end{array}$ \\
\hline EÖ1 & 20 & Arnavutluk & Hemşir-TÖMER & $20 \mathrm{k}$. \\
\hline EÖ2 & 20 & Rusya & İktisat-TÖMER & $20 \mathrm{dk}$. \\
\hline EÖ3 & 23 & Sudan & $\begin{array}{c}\text { TÖMER -YL. Uluslarası } \\
\text { İlişkiler }\end{array}$ & $18 \mathrm{dk}$ \\
\hline EÖ4 & 19 & Somali & $\begin{array}{c}\text { Bankacılık Ve Finansman- } \\
\text { TÖMER }\end{array}$ & $18 \mathrm{dk}$. \\
\hline EÖ5 & 19 & Afganistan & Kamu Yönetimi-TÖMER & $18 \mathrm{dk}$. \\
\hline
\end{tabular}

Tablo 3 verilerine göre beş erkek öğrenciden Türkçe hazırlık-TÖMER okuyan sonra ise yüksek lisans eğitimi görecek olan EÖ3öğrencisi, hariç diğerleri lisans öğrencileridir. Toplam beş erkek öğrencinin geldikleri ülkeler ise sırasıyla: Arnavutluk, Rusya, Sudan, Somali ve Afganistan 'dır. Uluslarası erkek öğrencilerin hepsinin Türkçe Hazırlık-TÖMER bölümünde oldukları tespit edilmiştir. Türkçe hazırlık okuyan uluslararası erekek öğrencilerin bir sonraki yıl, okuyacakları bölümler sırasıyla şunlardır: EÖ1 öğrencisi Hemşir, EÖ5 öğrencisi Kamu Yönetmi, EÖ4 öğrencisi Bankacılık ve Finasman,EÖ2 öğrencisi İktisat,EÖ3 öğrencisi ise Uluslararası İlişkilerdir. Uluslarası erkek öğrencilerin bir tane yüksek lisans öğrencisi hariç (23) diğerlerinin ortalama 1920 yaşlarındadırlar. Bu öğrencilerle okudukları üniversitede $18 \mathrm{dk}, 18 \mathrm{dk}, 18 \mathrm{dk}, 20 \mathrm{dk}, 20 \mathrm{dk}$ dakika olmak üzere toplamda $94 \mathrm{dk}, 1$ saat $5 \mathrm{dk}$ süreyle görüşmeler yapılmıştır.

Tablo4. Bir Dönemlik /Sömestır Okul Harcı Miktarı İle Dönem Başı Kitap Harcamalarının Miktarı

$\begin{array}{cccc}\text { Katılımcılar } & \text { Bölümler } & \begin{array}{c}\text { Bir Dönemlik } \\ \text { Okul Harcı Miktarı }\end{array} & \begin{array}{c}\text { Dönem Başı Kitap } \\ \text { Harcamaları }\end{array} \\ \text { KÖ1 } & \text { Tıp } & 900 \mathrm{TL} & 600 \mathrm{TL} \\ \text { KÖ2 } & \text { Tıр } & 900 \mathrm{TL} & 500 \mathrm{TL} \\ \text { KÖ3 } & \text { Türk Dili Ve Edebiyat1 } & 460 \mathrm{TL} & 300 \mathrm{TL} \\ \text { KÖ4 } & \text { Turizim } & 400 \mathrm{TL} & 300 \mathrm{TL}\end{array}$




$\begin{array}{cccc}\text { KÖ5 } & \text { İktisat } & 285 \mathrm{TL} & 150 \mathrm{TL} \\ \text { KÖ6 } & \text { Acil Yardım Ve Afet Yönetimi } & 285 \mathrm{TL} & 200 \mathrm{TL} \\ \text { KÖ7 } & \text { Aci Yardım Ve Afet Yönetimi } & 285 \mathrm{TL} & 200 \mathrm{TL} \\ \text { KÖ8 } & \text { Tıp } & \text { YOK } & 400 \mathrm{TL} \\ \text { KÖ9 } & \text { Sını Öğretmenliği } & \text { YOK } & 250 \mathrm{TL} \\ \text { KÖ10 } & \text { Hemşirelik } & \text { 285 TL } & 100 \mathrm{TL} \\ \text { KÖ11 } & \text { İlk Ve Acil Yardım } & 285 \mathrm{TL} & 200 \mathrm{TL} \\ \text { KÖ12 } & \text { İlahiyat } & \text { YOK } & 400 \mathrm{TL} \\ \text { KÖ13 } & \text { İlahiyat } & 436 \mathrm{TL} & 300 \mathrm{TL} \\ \text { KÖ14 } & \text { İlahiyat(2. Öğretim) } & & \\ \text { KÖ15 } & \text { PDR } & \text { 1500TL } & 500 \mathrm{TL} \\ & & 425 \mathrm{TL} & 500 \mathrm{TL}\end{array}$

Tablo 4 verilerine göre uluslarası kız öğrencilerinin okul harç miktarları ile döenm başı kitap harcamaları sırasıyla şöyledir: KÖ1 ve KÖ2'nin kitap harcamaları, 900 TL, iken dönem başı kitap harcamalar1 KÖ1'in 600 TL, KÖ2 ise 500 TL'dir. KÖ3'ün okul harç miktarı, 460 TL, iken dönem başı kitap harcamaları, 300 TL'dir. KÖ4'ün okul harç miktarı 400 TL iken dönem başı kitap harcamaları300tl dir. KÖ5, KÖ6,KÖ7, KÖ11,KÖ10'un okul harç miktarları 285 TL iken, KÖ5'in dönem başı kitap harcaması, 150 TL , KÖ6'ın dönem baş1 kitap harcaması, KÖ7'in ve KÖ11'in döenm başı kitap harcaması, 200 TL, KÖ10'ün dönem başı kitap harcaması 100 TL'dir. KÖ8 ile KÖ9'un Suriyeli olması dolaysıyla okul harç miktarları yoktur, KÖ8'in dönem başı kitap harcamaları 400 TL iken, KÖ9'un ise 250 tl'dir. KÖ12'nin Suriyeli olması dolayısıyla okul harcı yoktur, dönem başı kitap harcamaları ise 400 tldir. KÖ13'ün okul harç miktarı 436 TL iken, dönmebaşı kitap harcamaları ise 300 tl'dir. KÖ14'ün okul harç miktarı 1500 TL iken -ikinci öğretim öğrencisi olmasından dolayı-dönem başı kitap harcamaları ise 500 TLdir. KÖ15'in okul harç miktarı 425 TL iken, dönem başı kitap harcamaları ise 500 TL'dir. Tablo 4 verilerine göre, uluslarası kız öğrecnilerden, okul harç mikatarını, ikinci öğretim öğrencisi olan KÖ14'ün en fazla $1500 \mathrm{TL}$, ödediğini bunu ise tıp öğrencileri $900 \mathrm{TL}-\mathrm{KÖ1,KÖ2}$ 'in izlemekte olduğu tespit edilmiştir. 
Tablo 4 verilerin göre uluslarası kız öğrencilerinden dönem başı kitap harcamalarında ise KÖ1, KÖ2-600 TL tıp öğrencileri ardından da ilahiyat KÖ14 ve PDR öğrencisi KÖ15-500 TL olduğu saptanmıştır.

Tablo 5. Bir Dönemlik/Sömestır Okul Harcı Miktarı İle Dönem Başı Kitap Harcamalarının

\section{Miktarl}

\begin{tabular}{|c|c|c|c|}
\hline Katılımcılar & Bölümler & $\begin{array}{l}\text { Bir Dönemlik Okul Harcı } \\
\text { Miktarı }\end{array}$ & $\begin{array}{l}\text { Dönem Başı Kitap } \\
\text { Harcamaları }\end{array}$ \\
\hline EÖ1 & Hemşirelik & $285 \mathrm{TL}$ & $300 \mathrm{TL}$ \\
\hline EÖ2 & TÖMER-İktisat & $1000 \mathrm{TL}$ & $890 \mathrm{TL}$ \\
\hline \multirow[t]{2}{*}{ EÖ3 } & TÖMER-Yüksek Lisans & $1000 \mathrm{TL}$ & $660 \mathrm{TL}$ \\
\hline & Uluslarası İlişkiler & & \\
\hline \multirow[t]{2}{*}{ EÖ4 } & TÖMER-Bankacılık ve & $1000 \mathrm{TL}$ & $635 \mathrm{TL}$ \\
\hline & Finansman & & \\
\hline EÖ5 & TÖMER-Kamu Yönetimi & $1000 \mathrm{TL}$ & $600 \mathrm{TL}$ \\
\hline
\end{tabular}

Tablo 5'e baktığımızda, EÖ1'in okul harç miktarı 285 TL iken dönem başı kitap harcaması ise 300 TL'dir. EÖ2, EÖ3, EÖ4 ve EÖ5'in okul harç miktarları 1000 TL iken, EÖ2'in dönem baş1 kitap harcamaları 890 TL, EÖ3'ün 660TL, EÖ5'in ise 600TL'dir. EÖ4'ün dönem başı kitap harcamaları ise 635TL'dir. Tablo 5 verilerinden hareketle, uluslararası erkek öğrencilerden Türkçe hazırlıkTÖMER okuyan öğrencilerin en fazla okul harcını ödedikleri söylenebilinir. Dönem başı kitap harcamalarına baktığımızda ise TÖMER okuyan iktisat öğrencisinin en fazla -890 TL harcama yaptığını söylenebilinir.

Tablo 6. Burs Alan Öğrenciler

Katılımcılar
KÖ 1
KÖ 2
KÖ 3
EÖ 4
EÖ5

$\begin{array}{cc}\text { Bölümler } & \text { Burs Miktarı } \\ \text { Hemşirelik } & 500 \mathrm{TL} \\ \text { Sınıf Öğretmenliği } & 300 \mathrm{TL} \\ \text { Tıp } & 1000 \mathrm{TL} \\ \text { TÖMER } & 1000 \mathrm{TL} \\ \text { TÖMER } & 2000 \mathrm{TL}\end{array}$


Araştırmamıza konu olan 20 tane uluslararası öğrenciden 5'i burs alırken diğer kalan 15 öğrenci ise burs almamaktadır. Burs alan beş öğrenciden ise 3'ü kız diğer ikisi ise erkek öğrencilerdir. Sırasıyla burs alan öğrencilerin burs miktarları şöyledir: KÖ1, 500 TL, KÖ2, 300TL, KÖ3 1000TL, EÖ4, 1000TL, EÖ5,2000TL burs almaktadır. Verilerden hareketle ulsularası erkek öğrencilerin sayı olarak kız öğrencilere kıyasen daha az kişi burs aldıkları; fakat bu burs miktarının k1z öğrencilere göre daha yüksek olduğu tespit edilmiştir.

Tablo 7. Uluslarası Öğrencilerin Yurt Ücretleri

$\begin{array}{cccc}\text { Kat1limc1lar } & \text { Yurt Ücretleri } & \text { KÖ7 } & 150 \mathrm{TL} \\ \text { KÖ1 } & 350 \mathrm{TL} & \text { KÖ8 } & 450 \mathrm{TL} \\ \text { KÖ2 } & 400 \mathrm{TL} & \text { KÖ9 } & 450 \mathrm{TL} \\ \text { KÖ3 } & 300 \mathrm{TL} & \text { KÖ10 } & 450 \mathrm{TL} \\ \text { KÖ4 } & 300 \mathrm{TL} & \text { KÖ11 } & 350 \mathrm{TL} \\ \text { KÖ5 } & 450 \mathrm{TL} & \text { EÖ1 } & 115 \mathrm{TL} \\ \text { KÖ6 } & 400 \mathrm{TL} & \text { EÖ2 } & 720 \mathrm{TL}\end{array}$

Araştırmamızda mevcut olan 20 öğrenciden 13 'ü yurtta ücretli kalmakta, diğer kalan 7 öğrenci ise ücretsiz kalmaktadır. Bu 13 öğrenciden kadın öğrencilere oranla erkek öğrencilerin hem maksimum hem de minimum arasında yurt ücretini ödediğini söyleyebiliriz. Örneğin bir erkek öğrenci 720 TL yurt ücreti öderken, diğer bir erkek öğrenci ise sadece 115 TL yurt ücreti ödemektedir. Kadın öğrencilerden (burslandırılmış) minimum burs ücreti fiyatı 150 TL iken, maksimum burs ücreti fiyatı ise 450 TL olduğu görülmüştür. Bunların arasında kalanlar ise 300350 TL civarında yurt ücreti ödemektedirler. Uluslarası öğrencilerin sırasıyla yurt ücretleri şöyledir: KÖ1, 350TL; KÖ2, 400TL;KÖ3,300TL;KÖ4,300TL; KÖ5,450TL;KÖ6,400TL;KÖ7, KÖ8,KÖ9,KÖ10,450TL;KÖ11,350TL; EÖ1,115TL,EÖ2,720TLcivarındadır.

Tablo 8. Uluslarası Kız ve Erkek Öğrencilerin Toplam Aylık Harcamaları 


\begin{tabular}{|c|c|c|c|c|c|c|}
\hline Katılımcılar & $\begin{array}{l}\text { Kiralık } \\
\text { Daire }\end{array}$ & Yurt & Beslenme & Giyim & $\begin{array}{l}\text { (Ulaşım)Y } \\
\text { ol }\end{array}$ & TOPLAM \\
\hline KÖ1-Sırbistan & & $\mathrm{X}$ & $\mathrm{X}$ & $\mathrm{X}$ & $\mathrm{X}$ & $650 \mathrm{TL}$ \\
\hline KÖ2 -Surbistan & & $\mathrm{X}$ & $\mathrm{X}$ & l & $\mathrm{X}$ & $500 \mathrm{TL}$ \\
\hline KÖ3 -Surbistan & & $\mathrm{X}$ & $\mathrm{X}$ & $\mathrm{X}$ & $\mathrm{X}$ & $600 \mathrm{TL}$ \\
\hline KÖ4- Misır & & $\mathrm{X}$ & $\mathrm{X}$ & l & $X$ & $800 \mathrm{TL}$ \\
\hline KÖ5 -Arnavutluk & & $\mathrm{X}$ & I & $\mathrm{X}$ & $\mathrm{X}$ & $600 \mathrm{TL}$ \\
\hline KÖ6 -Arnavutluk & & $\mathrm{X}$ & $\mathrm{X}$ & $\mathrm{X}$ & $\mathrm{X}$ & $500 \mathrm{TL}$ \\
\hline KÖ7- Arnavutluk & & $X$ & $X$ & $\mathrm{X}$ & $\mathrm{X}$ & $490 \mathrm{TL}$ \\
\hline KÖ8-Arnavutluk & & $\mathrm{X}$ & $\mathrm{X}$ & $\mathrm{X}$ & $\mathrm{X}$ & $600 \mathrm{TL}$ \\
\hline KÖ9-Türkmenistan & & $\mathrm{X}$ & l & $X$ & $\mathrm{X}$ & $700 \mathrm{TL}$ \\
\hline KÖ10-Kosova & & $\mathrm{X}$ & $\mathrm{X}$ & $\mathrm{X}$ & $\mathrm{X}$ & $450 \mathrm{TL}$ \\
\hline KÖ11-Kosova & & $\mathrm{X}$ & l & $\mathrm{X}$ & $\mathrm{X}$ & $500 \mathrm{TL}$ \\
\hline KÖ12-Suriye & & I & $\mathrm{X}$ & $\mathrm{X}$ & $\mathrm{X}$ & $600 \mathrm{TL}$ \\
\hline KÖ13-Suriye & & l & $\mathrm{X}$ & $\mathrm{X}$ & $\mathrm{X}$ & $400 \mathrm{TL}$ \\
\hline KÖ14-Irak & & $\mathrm{X}$ & l & $X$ & $X$ & $800 \mathrm{TL}$ \\
\hline KÖ15-Avusturya & & $\mathrm{X}$ & I & $\mathrm{X}$ & $\mathrm{X}$ & $850 \mathrm{TL}$ \\
\hline EÖ1-Arnavutluk & & $\mathrm{X}$ & $\mathrm{X}$ & $\mathrm{X}$ & $\mathrm{X}$ & $1395 \mathrm{TL}$ \\
\hline EÖ2- Rusya & $\mathrm{X}$ & & $\mathrm{X}$ & $\mathrm{X}$ & $\mathrm{X}$ & $2000 \mathrm{TL}$ \\
\hline EÖ3-Sudan & & l & $\mathrm{X}$ & $\mathrm{X}$ & $\mathrm{X}$ & $600 \mathrm{TL}$ \\
\hline EÖ4-Somali & & $X$ & $\mathrm{X}$ & $X$ & l & $900 \mathrm{TL}$ \\
\hline EÖ5-Afganistan & & l & $X$ & $\mathrm{X}$ & $\mathrm{X}$ & $600 \mathrm{TL}$ \\
\hline
\end{tabular}

Tablo 8 'e ( $\mathrm{X}$ işareti evet, / işareti ise hayır anlamına gelmektedir) baktığımızda, ulsulararası öğrencilerin, kiralık daire, yurt, beslenme, giyim ve yol masrafları için aylık ne kadar harcama 
yaptıkları tespit edilmiştir. Uluslarasrı öğrencilerden sadece Rusya'dan gelen tek bir öğrenci hariç diğerleri KYK, özel ve vakıf yurttlarında kalmaktadırlar. ' Ben burda ailemle yaşıyorum, iki kız ve bir kadın'”(EÖ2). Tablo 8'nin verilerine dayanarak aylık en fazla harcamayı Sırbistan, Somali, Irak, Avusturya, Mısır gibi ülkelerden gelen öğrencilerin yaptıkları tespit edilmiştir. Suriye-KÖ12, KÖ13, Sudan-EÖ3 ve Afganistan-EÖ5 öğrencilerinin yurtlarda burslu kaldıklarından yurt ücretleri yoktur. Uluslarası öğrencilerden, KÖ2 ve KÖ4 giyim harcamalarını, KÖ5 ve KÖ9, KÖ11, KÖ14,KÖ15- beslenme harcamalarını, EÖ4-ulaşım gibi harcamaların tutarını söylememişlerdir. Bunların nedenlerini ise şöyle belirtmişlerdir:

'Tıp okuyorum, kitaplarımız pahall, o yüzden çok fazla eşya almıyorum(KÖ2)', ' 'Çaraşfla kapalıyım, çok eşya almıyorum(KÖ4)'”.

' 'Yurtta çıkan yemekleri yemiyorum, pazardan bişeyler alıp kendim yapıyorum(KÖ5)', ' 'Yurttaki yemekleri yediğimden dışardan yemek almıyorum"'(KÖ9)'. Dışardan hiç yemek şiparişi vermiyorum(KÖ11). Yurtta çıkan yemeklerin tadını beğeniyoruz o yüzden dışardan yemek $\operatorname{almiyoruz}(K O ̈ 14, K \ddot{O} 15)$ ',

'’Bazen yürüyorum, bazen otobüs kullanıyorum, ulaşımın ne kadar tam bilmiyorum(EÖ3)',

Uluslarası öğrencilerden biri kiralık daire hariç, diğerleri hepsi KYK ve özel yurttlarda kalmaktadırlar. Uluslarası öğrencilerin yurt, beslenme, giyim ve yol masraflarının aylık harcamaları sırasıyla şöyledir: Kız öğrecniler; KÖ1-650 TL,KÖ2-500TL,KÖ3-600TL, KÖ4800TL, KÖ5-600TL, KÖ6-500TL, KÖ7-490TLKÖ8-600TL, KÖ9-700TL, KÖ10-450TL, KÖ11500TL, KÖ12-600, KÖ13-400TL, KÖ14-800TL, KÖ15-850TL; Erkek öğrenciler; EÖ1-1395TL, EÖ2-2000TL, EÖ3-600TL, EÖ4-900TL, ve EÖ5'in ise 600TL civarındadır. En yüksek toplam aylık harcama Rusya ülkesinden gelen EÖ2'i -2000TL; en düşün aylık harcama ise Suriye'den gelen KÖ13-400 TL 'dir.

Tablo 9. Uluslarası Öğrencilerin Ek İş İtiyaçlarının Olup Olmadı̆̆ına Dair Veriler

$\begin{array}{llll}\text { KÖ1-Sırbistan } & \text { Hayır } & \text { KÖ11-Kosova } & \text { Evet } \\ \text { KÖ2-Sırbistan } & \text { Hayır } & \text { KÖ12-Suriye } & \text { Evet } \\ \text { KÖ3 -Sırbistan } & \text { Evet } & \text { KÖ13-Suriye } & \text { Evet } \\ \text { KÖ4- Mısır } & \text { Hayır } & \text { KÖ14-Irak } & \text { Hayır } \\ \text { KÖ5-Arnavutluk } & \text { Evet } & \text { KÖ15-Avusturya } & \text { Hayır } \\ \text { KÖ6-Arnavutluk } & \text { Evet } & \text { EÖ1-Arnavutluk } & \text { Evet } \\ \text { KÖ7- Arnavutluk } & \text { Evet } & \text { EÖ2- Rusya } & \text { Hayır }\end{array}$




$\begin{array}{llll}\text { KÖ8-Arnavutluk } & \text { Evet } & \text { EÖ3-Sudan } & \text { Hayır } \\ \text { KÖ9-Türkmenistan } & \text { Evet } & \text { EÖ4-Somali } & \text { Hayır } \\ \text { KÖ10-Kosova } & \text { Evet } & \text { EÖ5-Afganistan } & \text { Hayır }\end{array}$

Tablo 9. verilerine göre uluslarası ögrencilerin 11 'i ek işe ihtiyacının olduğunu geri kalan 9'u ise ek işe ihtiyacının olmadığını belirtmişlerdir.

Tablo 10. Uluslararası Öğrencilerin Yaptıkları Dĭger Harcamalar

\begin{tabular}{|c|c|c|}
\hline Katılımcilar & Ülkeler & Diğer Harcamalar Kategorisi \\
\hline KÖ1 & Surbistan & $\begin{array}{l}\text { "Yllda iki ya da üç kere eve gidiyorum. Ortalama fiyat } 400 T L . \text { Boş } \\
\text { zamanlarımda dlşarl çıklyorum. Arkadaşlarımla tatl yiyorum bunun için } 15 \\
\text { TL harclyorum(KÖ1)". }\end{array}$ \\
\hline KÖ2 & Arnavutluk & $\begin{array}{l}\text { 'Üniversite dönemi sonunda ülkeme gitmek için } 150 \text { TL para } \\
\text { harclyorum"'(KÖ2). }\end{array}$ \\
\hline KÖ3 & Arnavutluk & $\begin{array}{l}\text { 'Klyafet, yemek ve arakadaşlarımla sinemeya gitmek için para harcıyorum. } \\
\text { Bunlar da yaklaşı olarak } 50 \text { TL dir(KÖ3)'". }\end{array}$ \\
\hline KÖ4 & Sirbistan & $\begin{array}{l}\text { "Üniversite dönemi sonunda ülkeme gitmek için } 350 \text { TL para } \\
\text { harclyorum(KÖ4)". }\end{array}$ \\
\hline KÖ5 & Kosova & $\begin{array}{l}\text { 'Üniversite dönemi sonunda ülkeme gitmek için } 300 \text { TL para } \\
\text { harclyorum(KÖ5)'.' }\end{array}$ \\
\hline KÖ6 & Arnavutluk & $\begin{array}{l}\text { "Arkadaşlarımla gezmek ve dişarda yemek yemek, için } 500 \text { TL para } \\
\text { harclyorum(KÖ6)". }\end{array}$ \\
\hline KÖ7 & Arnavutluk & 'Değişik yerleri görmek, gezmek için 400 TL para harcıyorum(KÖ7)'”. \\
\hline KÖ8 & Suriye & $\begin{array}{l}\text { "Okulda sunum yapmak, arkadaşlarımla piknik yapmak için para harcarım. } \\
\text { Bu yıl bilgisayarım bozuldu. Tamirciye } 200 \text { TL para verdim(KÖ8)". }\end{array}$ \\
\hline KÖ9 & Türkmenistan & $\begin{array}{l}\text { "Okuduğum bölümümle ilgili sunum yapmak için ve bazı tarihi yerleri } \\
\text { gezmek için } 400 \text { TL para harcarım. Uçak biletim yaklaşık olarak } 2500 \text { TL } \\
\text { civarında olduğu için sadece haziran tatilinde memleketime } \\
\text { gidiyorum(KÖ9)'". }\end{array}$ \\
\hline KÖ10 & Avusturya & 'Bilet parası için 2500 TL para harcıyorum(KÖ10)'”. \\
\hline KÖ11 & Misir & $\begin{array}{l}\text { 'Ülkeme gidiş-dönüş̧ uçak biletim yaklaşık olarak } 4000 t l \\
\text { civarındadır(KÖ11)". }\end{array}$ \\
\hline KÖ12 & Kosova & $\begin{array}{l}\text { "'Kişisel bakımıma önem verdiğim için bakım ürünlerine } 500 \text { TL harcama } \\
\text { yapıyorum(KÖ12)". }\end{array}$ \\
\hline KÖ13 & Irak & ''Eve dönüş bilet param 200 TL $\operatorname{dir}(K O ̈ 13)$ '.' \\
\hline
\end{tabular}




\begin{tabular}{|c|c|c|}
\hline KÖ14 & Suriye & $\begin{array}{l}\text { 'Her zaman olmasa da bazen bir ya da iki dönemlik toplam Tıbbi aletler, ek } \\
\text { kitaplar için } 1000 \text { TL harcama yaparım(KÖ14)'". }\end{array}$ \\
\hline KÖ15 & Sirbistan & $\begin{array}{l}\text { 'Kitaplarım ve notlarım için } 400 \text { TL, eve dönüs uçak biletim için } 300 \text { TL ve } \\
\text { arada arakadaşlarımla gezilere katılmak için de } 150 \text { TL para } \\
\text { harclyorum(KÖ15)". }\end{array}$ \\
\hline EÖ1 & Somali & $\begin{array}{l}\text { "Arkadaşlarımla iskeleye gitmek, yemek yemek için } 200 \text { TL para } \\
\text { harclyorum(EÖ1)'. }\end{array}$ \\
\hline EÖ2 & Sudan & $\begin{array}{l}\text { 'Memleketime gidiş uçak biletim için yaklaşık olarak 1000-1500 TL para } \\
\text { harclyorum(EÖ2)'. }\end{array}$ \\
\hline EÖ3 & Afganistan & "Arkadaşlarımla gezmek için 100 TL para harcıyorum(EÖ3)'. \\
\hline EÖ4 & Arnavutluk & '‘Ülkeme gitmek için 150 TL para harciyorum(EÖ4)'.' \\
\hline EÖ5 & Rusya & $\begin{array}{l}\text { "Çok para harcamiyorum. Bazen canlı müzik dinlemek için } 15 \text { TL para } \\
\text { harclyorum(EÖ5)'. }\end{array}$ \\
\hline
\end{tabular}

Tablo 10'da Uluslararası öğrencilerin, diğer harcamalar kategorisinde, kişisel harcamalar kodunda, ulaşım ücretleri, eğlence, gezi, araç-gereç temini, dışarda yemek yeme, arıza sorunları yer almaktadır. Uluslararası öğrecnilerin yaomış oldukları diğer harcamalar kategorisine baktığımızda en fazla harcamayı memeleketlerine dönmek için, aldıkları bileti fiyatları oluşturmaktadır. Uçak bileti fiyatları 2500TL civarındadır. En yüksek uçak bileti fiyatları olan öğrenciler, Türkmenistanlı, Avusturyalı, Mısırlı ve Sudanlı öğrencilerdir. Uluslararası öğrencilerin otobüs fiyatları ise 200 TL civarındadır. Tıp okuyan uluslarası öğrencilerin çeşitli tıbbı cihazlar, ek kitaplar harcamları yaklaşık olarak 1000 TL civarındadır. Arkadaşlarıyla birlikte gezmek, yemek yemek, eğlenmek, tarihi yerleri ziyaret etmek gibi yapılan bir diğer harcamalar yaklaşık 500 TL civarındadır.

\section{Sonuç Ve Öneriler}

Araştırmaya katılan on beş uluslararası kadın öğrencilerin İlahiyat, Tıp, PDR, Sınıf Öğretmenliği, Hemşirelik, Acil Yardım Ve Afet Yönetimi, İlk Ve Acil Yardım, Türk Dili Ve Edebiyati ile Turizm Bölümlerini tercih ettikleri, uluslararası beş tane erkek öğrencilerin ise İktisat, Bankacılık Ve Finansman, Hemşir gibi bölümleri tercih ettikleri tespit edilmiştir.

Uluslararası öğrencilerin yükseköğretim harcamalarına genel olarak baktığımızda, TÖMER okuyan öğrencilerin daha fazla harcama yaptıklarını görebiliriz, bu öğrencilerin öğrenim harçları 
ve kitap masrafları diğer öğrencilere oranla daha yüksektir. Bu öğrencilerin dönem başı harç miktarları 1000 TL civarında iken, kitap harcamaları ise 660 TL ile 890 TL arasındadır. Bunun dışında Tıp öğrencilerinin dönem başı okul harç miktarı 900 TL iken,kitap harcamaları ise 600 TL ile 500 TL arasındadır. İkinci öğretim ilahiyat öğrencilerin harç mikatarları 1500 TL, kitap harcamaları ise Diğer bölümde okuyan öğrencilerin ise ortalama harç mikatarları ise $285 \mathrm{TL}$ başlayarak 500 TL civarındadır. Uluslararsı öğrencilerin çoğu burs almamaktadır. Yurt ücretleri ise 115 TL başalayarak 450 TL kadar çıkmaktadır. Toplam aylık harcamaları kiralık evde yaşayan tek bir öğrenci hariç 2000 TL diğerlerinin(yurt, beslenme, giyim ve yol) 900 TL civarındadır. Öğrencilerin çoğu ek işe ihtiyaç duymaktadırlar. Bunun dışında, öğrencilerin yaptıkları diğer harcamaların tutarı, uçak ve otobüs biletleri hariç yaklaşık olarak 500-1000 TL civarındadır. Ayrıca bu öğrencilerin 15 'nin burs almadığını, sadece 5' in 500 TL den başlayarak 1000TL-2000 TL civarında burs aldığı söylenebilinir. Genel olarak baktığımızda, uluslararsı öğrencilerin çoğunun ek işe ihtiyaçlarının olduğunu ve çoğunun da burs almadığı tespit edilmiş̧ir.Güçlü 1997 yaptığı çalışmasında, uluslararası öğrencilerin mali yardım konusunda en fazla güçlük çektikleri sorunlardan biri olduğunu; Kaçmazoğlu ve Şeker, 1998 ile Çağlar'ın 1999 ise yaptıkları çalışmalarında, uluslarası öğrenclerin düşük mikatralarda burs aldıklarını tespit etmişlerdir. Açıkalın ve ark. (1996) ise, çalışmalarında, uluslararası öğrencilerin Başbakanlık burslarını yetersiz bulduklarını belirlemişlerdir. Bütün bu çalışmaların tespitinden sonra şu öneriler yapılabilir: Öğrenim harc1 yüksek olan uluslararası öğrencilerin, harçları düşürülmeli veya kaldırılmalı, daha çok burs imkanları sağlanmalıdır. Ailelerinin gelir durumları göz önünde bulundurularak, uygun fiyatlarda barınma, beslenme, kitap, ulaşım vb. imkanlar sağlanmalıdır. Uluslarası öğrencilerin yükseköğrenim harcamaları ile ilgili çalışmalar az olduğundan, bu alanla ilgili daha çok çalışmalara yer verilmesi yararlı olacaktır.

\section{Kaynakça}

Açıkalın, A., Demirel, Ö., \& Önsoy, R. (1996). Türkiye'de yükseköğrenim gören Türk cumhuriyetleri öğrencilerinin sorunları. Pegem A Yayıncılık: Ankara.

Çağlar, A. (1999). Türk üniversitelerinde öğrenim gören Türk cumhuriyetleri ve akraba toplulukları öğrencilerin sorunları. TODAİE Amme İdaresi Dergisi, 32 (4), 133-169. 
Gibbons, M. (1998). Higher education relevance in the 21st Century. Paper presented at UNESCO World Conference on Higher Education. Paris (pp. 27-28).

Güçlü, N. (1997). Transnational student mobility. Hacettepe Üniversitesi Eğitim Fakültesi Dergisi, $13,33-40$.

Kaçmazoğlu, H. B., \& Şeker, H. (1998). Türk cumhuriyetleri, türk ve akraba topluluklarından gelen öğrencilerin Türkiye ve kendi ülkeleriyle ilgili gözlemlerine dayanarak ortaya koydukları sorunlar: Atatürk Üniversitesi örneği. Sosyoloji Bilimler Enstitüsü, 1(1-2), 86104.

Mammadov, R, Baykara, B, Karimov, B (2020). Uluslarası Öğrencilerin Harcama Eğilimleri Ve Şehir Ekonomisine Katkıları: Eskişehir/Türkiye Örneği, Elm və İnnovativ Texnologiyalar Jurnal1, Nömrə 13, 2020. 69- 89.

Merriam, S. B. (2009). Qualitative research: A guide to design and interpretation. San Francisco: JosseyBass.

Radmard, S. Türk Üniversitelerindeki Uluslararası Öğrencilerin Yükseköğretim Taleplerini Etkileyen Etkenlerin İncelenmesi, Yükseköğretim Ve Bilim Dergisi, Cilt 7, Sayı 1, İstanbul-2017. Sayfa:67-77.

Uluslararsı Yükseköğretim Ve Türkiye'nin Konumu, DEİK (Dış İlişkiler Kurumu) İstanbul, 2013. Yalçın, A. (2019). Yükseköğretime Bakış 2019, İzleme Ve Değerlendirme Raporu, Eğitim-BirSen Yayınları: 96, Ankara.

Yıılırım, A. \& Şimşek, H. (2011). Sosyal bilimlerde nitel araştırma yöntemleri. Seçkin Yayıncılık: Ankara.

Yükseköğretim Kurulu (YÖK). (2007). Türkiye’nin yükseköğretim stratejisi. Ankara, https://www.yok.gov.tr adresinden 10 aralık 2019 tarihinde alındı. 